\title{
Morphophysiological characteristics of okra plants submitted to saline stress in soil with organic fertilizer
}

\author{
'University of International Integration of Afro-Brazilian Lusophony, Redenção, Brazil \\ ${ }^{2}$ Federal University of Ceará, Fortaleza, Brazil \\ *Corresponding author, e-mail: jonnathanagro@gmail.com
}

Geocleber Gomes de Sousa ${ }^{\circledR}$, Andreza de Melo Mendonça $^{2}$, Jonnathan Richeds da Silva Sales ${ }^{1 *(0)}$ Francisco Barroso da Silva Junior ${ }^{\circledR}$, João Gutemberg Leite Moraes ${ }^{\circledR}$, José Thomas Machado de Sousa' ${ }^{\circledR}$

\begin{abstract}
The excess of salts may compromise the growth and physiological functions of plants, but the use of bovine organic fertilizer can mitigate these effects. It was intended was to evaluate the saline stress in soil with and without bovine organic fertilizer on the initial growth, the accumulation of biomass and the gas exchanges of the okra culture. The test was conducted at the UNILAB's experimental farm, in Piroás, in Redenção - CE city. The treatments were distributed in a completely randomized design with five replications, in a $5 \times 2$ factorial concerning five irrigation water salinity levels $\left(1.0 ; 2.0 ; 3.0 ; 4.0\right.$ and $5.0 \mathrm{dS} \mathrm{m}^{-1}$ ), in the presence and absence of bovine organic fertilizer. Plant height, stem diameter, root length, a dry mass of shoot, photosynthesis, transpiration and stomatal conductance were evaluated. The bovine organic fertilizer promoted better means in initial growth and biomass in okra plants compared to the control treatment, thus showing efficiency in the attenuation of the salts present in irrigation water. The increase in the saline concentration of the irrigation water reduced the gas exchange (photosynthesis, stomatal conductance and transpiration) in okra plants. Nonetheless, in smaller proportions in the soil with the bovine organic fertilizer.
\end{abstract}

Keywords: Abelmoschus esculentus (L.), organic fertilizer, salinity

\section{Introduction}

The okra (Abelmoschus esculentus (L.) Moench) is a vegetable of African origin belonging to the family of Malvaceae, with annual production, shrubby, rich in carbohydrates, proteins, vitamins, minerals and unsaturated fats. This culture is very well suited to family farming, especially because of the high number of labor services in the harvesting, sorting and packing operations, in addition to the precocity in production and a relatively long harvest period and a good income alternative for the small farmer (Filgueira, 2012).

In Brazil, there are excellent conditions for the cultivation of okra, mainly in relation to the climate, being popularly cultivated in the Northeast and Southeast (Mota et al., 2008). According to data from the Agricultural Census, in the year 2017, Brazil produced about 128,460 tons of okra, the Northeast being the second largest producer with 32,337 tons, corresponding to $25.1 \%$ of the national production (IBGE, 2019). In the Brazilian semiarid region, irrigation is a fundamental practice to obtain high productivity, however, salts present in water and soil constitute a major obstacle to the production system, because salt stress inhibits plant growth and gas exchanges, thus compromising the productive aspects (Guedes Filho et al., 2015; Sousa et al., 2018; Andrade et al., 2019).

According to Freire et al. (2016), high soluble salt concentrations decrease the osmotic potential of the soil solution and hinder water uptake by plants, or toxic levels of some elements, especially sodium, chlorine and boron, causing nutritional imbalances and toxicity.

Nascimento et al. (2017) concluded, by evaluating the vegetative growth of okra as a function of irrigation water salinity, that the height of the plant and the okra stem diameter showed a negative response to the increase of the salinity of the applied water. Shahid 
et al. (2011) verified that increased salinity caused a decrease in shoot length and root length, photosynthesis rate and stomatal conductance for okra culture.

A promising alternative that minimizes the effects of saline stress on soil and plants is the use of organic fertilizers (Gomes et al., 2015). The organic fertilizer is a byproduct obtained from the fermentation of agricultural residues or animal waste that can substitute or supplement the chemical fertilization (Sousa et al., 2013a), being applied via soil or in the composting preparation (Dhiman
\& Dubey, 2017) for plant nutrition and in soil irrigated with saline water. Sousa et al. (2018) using the bovine organic fertilizer in the initial growth and in the exchanges in soybean plants irrigated with salt water also found an attenuating effect of this organic input for saline stress treatments.

The objective was to evaluate the saline stress in soil with and without bovine organic fertilizer on the initial growth, the accumulation of biomass and the gas exchanges of the okra culture.

Table 1. Soil chemical characteristics before treatment application.

\begin{tabular}{|c|c|c|c|c|c|c|c|c|c|c|c|}
\hline SOM & $\mathrm{N}$ & $\mathrm{Ca}^{2+}$ & $\mathrm{K}^{+}$ & $\mathrm{Mg}^{2+}$ & $\mathrm{Na}^{+}$ & $\mathrm{H}^{+}+\mathrm{Al}^{3+}$ & $\mathrm{Al}$ & SB & P & CEC & V \\
\hline \multicolumn{2}{|c|}{$\left(g_{k g}^{-1}\right)$} & & \multicolumn{5}{|c|}{$\left(\mathrm{cmol}_{\mathrm{c}} \mathrm{kg}^{-1}\right)$} & \multicolumn{3}{|c|}{$\mathrm{mg} \mathrm{kg}^{-1}$} & (\%) \\
\hline 5.28 & 0.31 & 2.3 & 0.27 & 2.7 & 0.05 & 0.99 & 0.05 & 5.3 & 56 & 6.7 & 84 \\
\hline
\end{tabular}

\section{Material and Methods}

The experiment was carried out from September to November 2017, in the area of the Piroás Experimental Farm, at the University of International Integration of AfroBrazilian Lusophony (NILAB), located in Redenção, Ceará, in the Maciço de Baturité region. According to Köppen, the local climate is classified as BSh '. The material used as substrate was classified according to the Brazilian soil classification system as Argisol Red Yellow (Santos et al. 2018), whose analysis of chemical attributes can be seen in Table 1.

The okra cultivar used in the experiment was Santa Cruz 47. The plants were sown in Styrofoam trays and, at 15 days, were transplanted into drained plastic containers with a capacity of 14 liters. The experimental test was conducted in full sun conditions. The experimental design was completely randomized in a $5 \times 2$ factorial scheme for the 5 levels of electrical conductivity of the

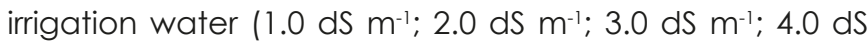

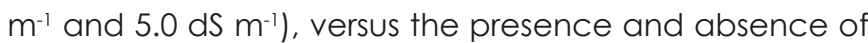
bovine organic fertilizer, with 5 repetitions, making a total of 50 experimental units.

The cultural treatments used in the experiment were: weed control, carried out manually whenever necessary. It was not necessary to use phytosanitary products to control phyto-diseases.

Irrigation was performed on a daily basis using the pot weighing method (Puértolas et al., 2017), supplying the volume of water every $24 \mathrm{~h}$ to maintain the substrate with humidity corresponding to $90 \%$ of the field capacity. The amount of $\mathrm{NaCl}, \mathrm{CaCl}_{2} \cdot 2 \mathrm{H}_{2} \mathrm{O}, \mathrm{MgCl}_{2} \cdot 6 \mathrm{H}_{2} \mathrm{O}$, salts used in the preparation of the irrigation water, was determined in order to obtain the desired ECW (electrical conductivity of water) in the ratio 7:2:1 (Rhoades et al., 2000) as shown in Table 2. Irrigation with water of different salt levels was started eight days after transplanting (DAT) and establishment of the seedlings.

The organic bovine fertilizer was prepared from a mixture of equal parts of fresh manure and non-saline water under aerobic fermentation for 30 days in a plastic container. The organic fertilizer was applied twice (at 8 and 16 DAT) in volumes equivalent to $10 \%(700 \mathrm{~mL}$

Table 2. Chemical characteristics of the waters used in the experiment.

\begin{tabular}{ccccccc}
\hline \multicolumn{7}{c}{ Water electric conductivity $\left(\mathrm{dS} \mathrm{\textrm {m } ^ { - 1 }}\right)$} \\
\hline Attributes & 0.25 & 1.0 & 2.0 & 3.0 & 4.0 & 5.0 \\
\cline { 2 - 7 } $\mathrm{pH}$ & 6.9 & 6.5 & 7.2 & 7.1 & 7.3 & 7.3 \\
$\mathrm{SO}_{4}^{2-}$ & --- & --- & --- & --- & --- & --- \\
$\mathrm{Mg}^{2+}$ & 1.4 & 3.9 & 5.3 & 4.2 & 5.4 & 9.6 \\
$\mathrm{Na}^{+}$ & 0.4 & 9.5 & 18.2 & 19.0 & 16.5 & 21.4 \\
$\mathrm{~K}^{+}$ & 0.2 & 0.2 & 0.2 & 0.2 & 0.2 & 0.2 \\
$\mathrm{Ca}^{2+}$ & 0.6 & 2.2 & 3.1 & 3.9 & 7.4 & 8.8 \\
$\mathrm{CO}_{3}^{2-}$ & --- & --- & --- & --- & --- & --- \\
$\mathrm{HCO}_{3-}$ & 0.1 & 0.1 & 0.1 & 0.1 & 0.1 & 0.1 \\
$\mathrm{Cl}^{-2}$ & 2.5 & 16.2 & 27.0 & 27.4 & 29.5 & 39.4 \\
SAR $\left(\mathrm{mmol}^{-1}\right)$ & 0.25 & 3.83 & 8.9 & 9.44 & 6.51 & 7.05 \\
Classification & $\mathrm{C}_{2} \mathrm{~S}_{1}$ & $\mathrm{C}_{3} \mathrm{~S}_{1}$ & $\mathrm{C}_{4} \mathrm{~S}_{3}$ & $\mathrm{C}_{4} \mathrm{~S}_{3}$ & $\mathrm{C}_{4} \mathrm{~S}_{2}$ & $\mathrm{C}_{4} \mathrm{~S}_{2}$ \\
\hline
\end{tabular}


plant ${ }^{-1}$ ) of the volume of the substrate. The chemical composition of the biofertilizer was analyzed according to the methodology suggested by Malavolta et al. (1997) is shown in Table 3.

At 45 days after sowing (DAT), the following variables were evaluated: plant height $(\mathrm{PH})$ using graduated measuring tape, stem diameter (SD) with digital caliper, root length (RL) with a graduated ruler, net photosynthetic rate (A), transpiration rate (E) and stomatal conductance (gs). Measurements were performed using an infrared gas analyzer (LCi system, ADC, Hoddesdon,
UK), in an open system, with airflow of $300 \mathrm{ml} \mathrm{min}^{-1}$.

For the dry mass of shoot (SDM) and root (RDM), the plants were conditioned in identified paper bags and placed in an oven at $60^{\circ} \mathrm{C}$ until reaching a constant value of dry matter. The total dry mass was composed of SDM + RDM.

The observed data were submitted to analysis of variance by the $\mathrm{F}$ test, those referring to the biofertilizer were compared by the Tukey test and those of a quantitative nature by regression. For data processing, the computer program ASSISTAT 7.7 BETA was used.

Table 3. Composition of macro and micronutrients in the dry matter of bovine organic fertilizer.

\begin{tabular}{ccccccccc}
\hline $\mathrm{N}$ & $\mathrm{P}$ & $\mathrm{K}$ & $\mathrm{Ca}$ & $\mathrm{Mg}$ & $\mathrm{Fe}$ & $\mathrm{Cu}$ & $\mathrm{Zn}$ & $\mathrm{Mn}$ \\
\hline & \multicolumn{4}{c}{$\mathrm{g} \mathrm{L}^{-1}$} & & & \multicolumn{4}{c}{$\mathrm{mg} \mathrm{L}^{-1}$} & \\
\hline 2.73 & 3.1 & 2.3 & 3.1 & 0.6 & 42.6 & 0.2 & 6.1 & 6.1 \\
\hline
\end{tabular}

\section{Results and Discussion}

In the analysis of variance presented in Table 4, it was found that the plant height, stem diameter, root length, shoot dry matter, dry matter of root and total dry matter responded to separate effects of salinity levels of irrigation water and organic fertilizer. In the net photosynthetic rate, transpiration rate and stomatal conductance, it was verified that there was a significant influence in significance level of 1 and $5 \%$ by the $F$ test for the salinity interaction of irrigation water versus bovine organic fertilizer.

The plant height responded in isolation to the water salinity levels (Figure 1A). Irrigation with water of up to $2.01 \mathrm{dS} \mathrm{m}^{-1}$ did not inhibit plant growth reaching the maximum value of $39.26 \mathrm{~cm}$. However, as waters with conductivity above this value, on the contrary, resulted in growth inhibition, presenting the lowest value of $32.44 \mathrm{~cm}$ at $5.00 \mathrm{dS} \mathrm{m}^{-1}$, a reduction of $17.37 \%$.

Table 4. Summary of variance analysis for plant height (PH), stem diameter (SD), root length (RL), shoot dry matter (SDM), root dry matter (RDM), total dry matter (TDM), net photosynthetic rate (A), transpiration rate (E) and stomatal conductance (gs) of okra plants depending on the levels of salinity of soil in irrigation water with and without bovine organic fertilizer.

\begin{tabular}{|c|c|c|c|c|c|c|c|c|c|c|}
\hline \multirow{2}{*}{ SV } & \multicolumn{10}{|c|}{ Middle square } \\
\hline & DF & $\mathrm{PH}$ & SD & $\mathrm{RL}$ & SDM & RDM & TDM & A & $E$ & gs \\
\hline Treatments & 9 & $60.69 *$ & $8.09 * *$ & $36.04^{* *}$ & $21.78^{* *}$ & $9.82^{*}$ & $80.37^{* *}$ & $33.35^{* *}$ & $1.99 * *$ & $0.02^{* *}$ \\
\hline Salinity (S) & 4 & $83.68^{* *}$ & $4.03^{*}$ & $50.57^{* *}$ & $25.23^{*}$ & $9.47^{*}$ & $101.38^{* *}$ & $26.49^{* *}$ & $2.38^{* *}$ & $0.04^{* *}$ \\
\hline Biofertilizer (B) & 1 & $149.64 *$ & $48.62^{* *}$ & $106.58^{* *}$ & $72.72^{* *}$ & $47.14^{* *}$ & $283.45^{* *}$ & $47.58^{* *}$ & $4.47^{* *}$ & $0.05^{* *}$ \\
\hline$B \times S$ & 4 & $15.47^{\mathrm{ns}}$ & $2.02^{\mathrm{ns}}$ & $3.88^{\text {ns }}$ & $5.61^{\mathrm{ns}}$ & $0.83^{\text {ns }}$ & $8.60^{\text {ns }}$ & $36.66^{* *}$ & $0.99 *$ & $0.01 *$ \\
\hline Residue & 40 & 21.15 & 1.21 & 7.29 & 7.22 & 3.58 & 13.32 & 4.76 & 0.34 & 0 \\
\hline $\mathrm{OA}$ & & 36.99 & 9.81 & 20.48 & 8.64 & 4.12 & 13.04 & 30.66 & 11 & 0.57 \\
\hline CV (\%) & & 12.43 & 11.21 & 13.18 & 31.1 & 35.94 & 27.98 & 7.12 & 33.7 & 10.27 \\
\hline
\end{tabular}

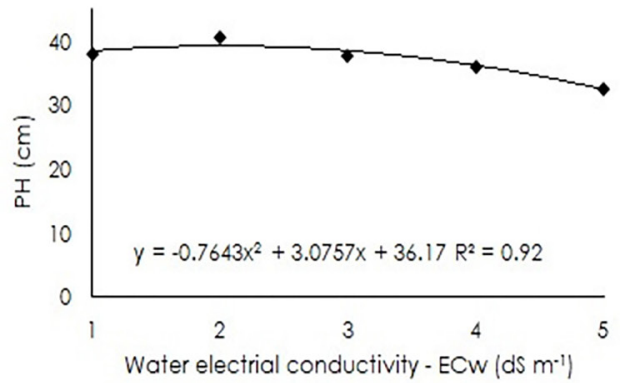

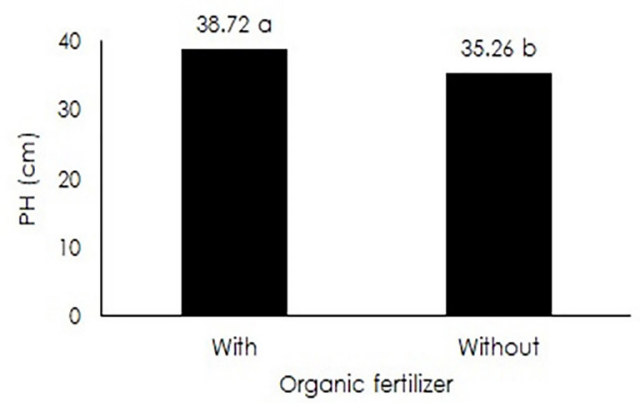

Figure 1. Height of okra plants (PH) with different levels of salinity in irrigation (A) and in soil with and without bovine organic fertilizer (B). Means followed by different letters in the column are statistically different by Tukey test at 0.05 probability level. 
In the presence of salts, there is an increase in the osmotic pressure of the medium, which will consequently reduce the water available to the plants, which will also affect the elongation of the cells and consequently the height of the plants (Oliveira et al., 2014).

Similar results of decreasing plant height were found by Sousa et al. (2017) in the irrigation of sesame plants with different levels of saline water. The same was also observed by Sousa et al. (2018) by evaluating the effect of irrigation water salinity on soybean culture growth on soil with bovine organic fertilizer.

It can be seen in Figure 1B that the treatments with bovine organic fertilizer resulted in higher $\mathrm{PH}$ values. $(38.72 \mathrm{~cm})$ in relation to the soil without the organic input $(35.26 \mathrm{~cm})$ in okra plants. The superiority presented by the bovine organic fertilizer confirms the suggestion of García et al. (2018), by stating that humic substances act on the soil structure, thus promoting an important role in the development of the root system of plants, and consequently in their growth. Alencar et al. (2015), point out that the application of biofertilizer improves the physical quality of the soil, particularly with regard to water retention due to the increase in microporosity. It is also believed that the use of this form of organic fertilizer may favor the activity of the soil microbiota, also contributing to the improvement of physical properties.

A similar trend was obtained by Sousa et al. (2014b) when higher growth of peanut plants (Arachis hypogaea L.) in the presence of bovine organic fertilizer was obtained.

The increase in the salinity of irrigation water inhibited the growth of okra plants, which was verified by stem diameter, with a $16.7 \%$ reduction with increasing salt concentrations of 1.0 to $5.0 \mathrm{dS} \mathrm{m}^{-1}$ (Figure 2A). Such results are due, according to Taiz et al. (2017) because the excess of salts reduces water absorption, compromising meristematic activity and cell stretching.

B

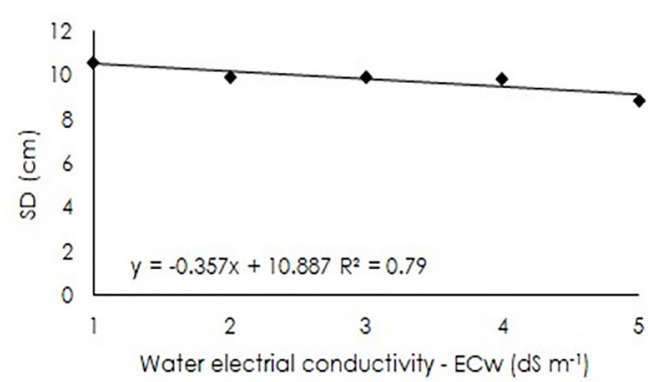

Figure 2. Stem diameter of okra plants (SD) with different levels of salinity in irrigation (A) and in soil with and without bovine organic fertilizer (B). Means followed by different letters in the column are statistically different by Tukey test at 0.01 probability level.

Corroborating with this information, Lima et al. (2015), evaluating the culture of the eggplant irrigated with water of increasing salinity used in irrigation, also obtained similar results to those of this study.

It can be noted that the use of bovine organic fertilizer favored the development of SD in comparison to the treatment without the presence of the organic input in okra plants (Figure 2B). This organic input promotes greater osmotic adjustments between the roots and the soil solution, minimizing the toxic effects of salts (Aydin et al., 2012), and releases humic substances into the soil, increasing the efficiency of water and nutrient absorption (Caron et al., 2015).

Similar results were obtained by Gomes et al. (2015), because in the treatments with organic fertilizer applied to the soil, the values of stem diameter were higher in relation to the soil without application of the input. Sousa et al. (2014b) obtained similar results, verifying a positive effect of the bovine organic fertilizer on the stem diameter of the peanut in relation to the soil without input.

It is observed in Figure $3 \mathrm{~A}$ that the root length was inhibited linearly insofar as the salt level increases, presenting a reduction of $5.9 \mathrm{~cm}(25.76 \%)$ between the lowest and the highest saline level.

The effect of salinity on root development is due, in part, to the fact that the roots are in direct contact with the salts of the medium (Guimarães et al., 2013). These results are consistent with those of Guimarães et al. (2013), where they verified that the root growth of the Mulungu seedlings was reduced linearly by the increase of the salinity of the irrigation water. These results also resemble those found by Coelho et al. (2014), which showed significant reductions in sorghum root length at

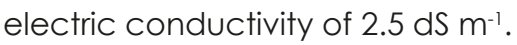

The average values presented in Figure 3B show that with the organic fertilizer the RL was higher $(21.94 \mathrm{~cm})$ in relation to the absence of the input $(19.02 \mathrm{~cm})$. It can 


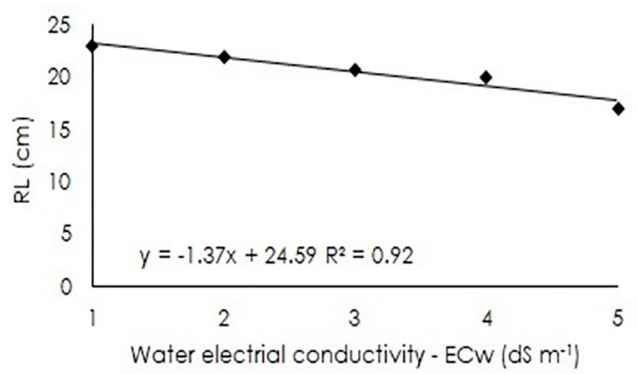

B

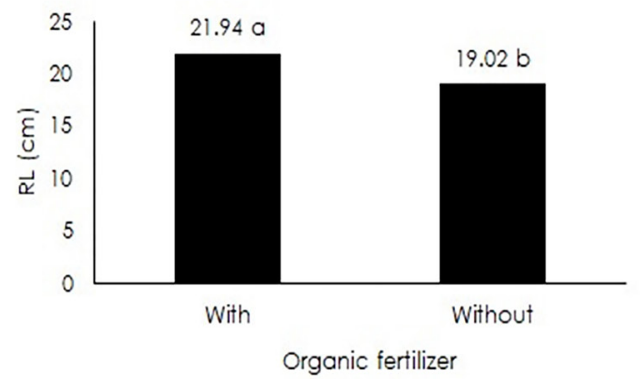

Figure 3. Root length of okra plants (RL) with different levels of salinity in irrigation (A) and in soil with and without bovine organic fertilizer (B). Means followed by different letters in the column are statistically different by Tukey test at 0.01 probability level.

be hypothesized that, in addition to the nutritional effect the bovine organic fertilizer applied to the surface of the substrate forms a barrier layer to the high losses of water by evaporation, which allows plant cells to remain turgid for longer in relation to plants that did not receive the input (Cavalcante et al., 2010).

Medeiros et al. (2011) observed that in soils with the presence of organic fertilizers these promoted greater root length of the tomato compared to the soil without any type of organic input. The same was observed by Véras et al. (2015), because they verified that the papaya seedlings that did not receive the doses of organic fertilizer reached smaller values of the analyzed variable.

The salinity affected in isolation the dry mass of

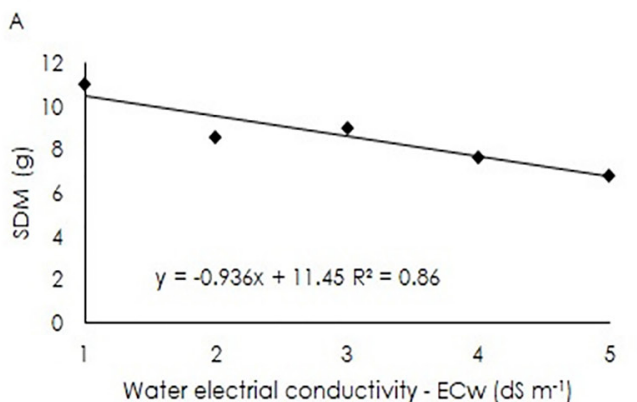

the aerial part (SDM) of the plants Figure 4A. Shows that it reduced linearly (38.04\%) according to the EC increase. It is worth mentioning that the decrease in biomass must have been caused, mainly, by the toxic effects of the salts absorbed by the plants and by the reduction of the total water potential caused by the increase in saline concentration (Lúcio et al., 2013).

Corroborating this statement, Sousa et al. (2016a), irrigating the radish culture with saline waters, registered trends similar to that of this study for this variable. A similar result was found by Reges et al. (2017), when they verified that increasing levels of irrigation water salts affected SDM in bell pepper plants.

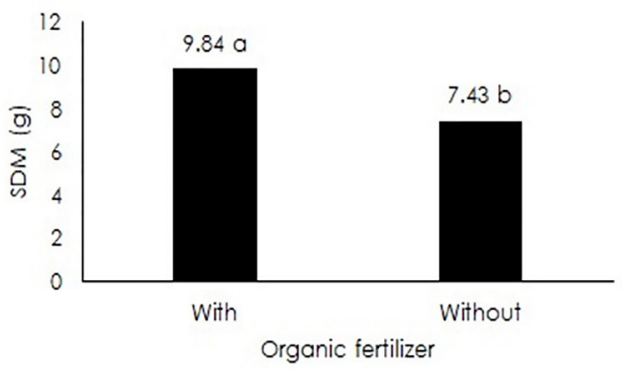

Figure 4. Shoot dry mass of okra plants (SDM) with different levels of salinity in irrigation (A) and in soil with and without bovine organic fertilizer (B). Means followed by different letters in the column are statistically different by Tukey test at 0.01 probability level.

It can be seen in Figure $4 \mathrm{~B}$ that in the treatments with bovine organic fertilizer, SDM values were higher $(9.84$ g) than in the absence of organic fertilizer (7.43 g) in okra plants. This result is justified due to the fact that the nitrogen provided by the bovine organic fertilizer promoted a higher allocation of aerial biomass, in addition to the humic substances also present in the organic bovine fertilizer, favor the water retention capacity and its larger amount of plants used (Balmori et al., 2014).

Contrary results were obtained by Reges et al. (2017), studying the bell pepper crop, in which the excessive fertilizer reduces the development of the plant under higher saline stress, affirm that the plants showed higher SDM in the treatments with the bovine organic fertilizer. Sousa et al. (2012b), in turn, in a work with corn, under different concentrations of bovine organic fertilizer, affirms that higher concentrations of organic matter lead to an increase in dry matter aerial part.

With regard to the net photosynthetic rate, it can be seen in Figure 5, that the quadratic polynomial model provided a maximum value of $34.23 \mathrm{~mol} \mathrm{~m}^{-2} \mathrm{~g}^{-1}$ for a ECW of $2.74 \mathrm{dS} \mathrm{m}^{-1}$ and $31.1607 \mathrm{~mol} \mathrm{~m}^{-2} \mathrm{~g}^{-1}$ in the same EC at $1.80 \mathrm{dS} \mathrm{m}^{-1}$, in the presence and absence of the bovine organic fertilizer, respectively. With the increase in saline 
concentration and, consequently, greater difficulty of the plant to absorb water from the soil, the plant needs to reduce the loss of water, resulting in a decrease in stomatal conductance. With the reduction of stomatal conductance and consequent stomatal closure, some parameters such as liquid photosynthesis and water use efficiency change (Oliveira et al., 2017).

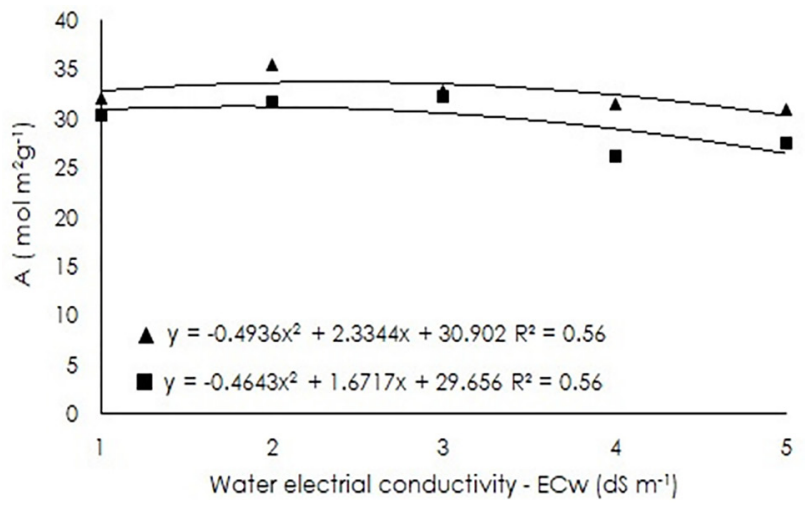

Figure 5. Net photosynthetic rate (A) in okra plants with different levels of salinity in irrigation in soil with (A) and without (घ) bovine organic fertilizer.

However, when using animal organic fertilizer (bovine), an attenuating effect occurs in plants irrigated with saline water, as reported by Gomes et al. (2015) when studying photosynthesis in the sunflower culture and Sousa et al. (2018) in soybean culture.

Figure 6 refers to the stomatal conductance, demonstrating that it was negatively affected by the salinity of the irrigation water, so that the data conformed to the quadratic model of polynomial regression for the absence of the bovine organic fertilizer and linear decreasing when the organic fertilizer was present. The first one showed a decrease at $2.54 \mathrm{dS} \mathrm{m}^{-1}(0.5744 \mathrm{mo}$ $\mathrm{m}^{-2} \mathrm{~g}^{-1}$ ) and the second one declined $36.98 \%$ (0.73 to 0.46).

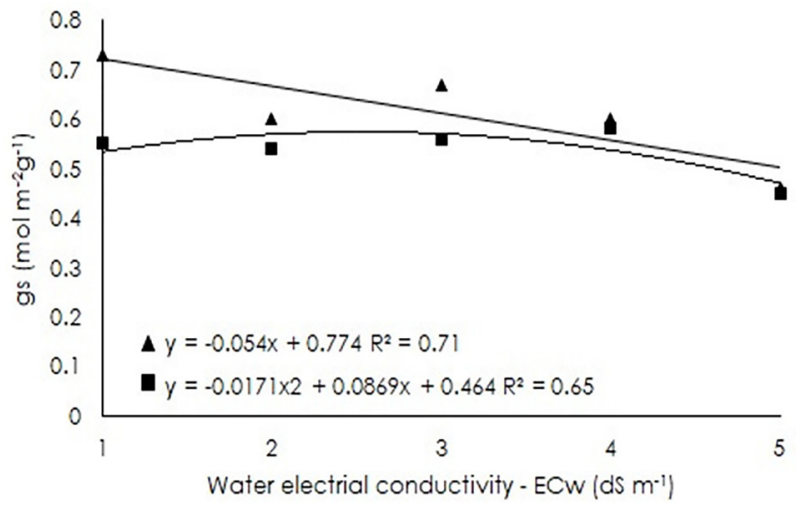

Figure 6. Stomatal conductance values (gs) in okra plants irrigated with different levels of salinity in irrigation in soil with $(\Delta)$ and without (घ) bovine organic fertilizer.

Although the mathematical model differed in both treatments, the plants presented greater resistance to saline stress when the organic fertilizer was applied. This is possibly due to an improvement in the nutritional supply to the plant as a consequence of the action of the humic substances released by the application of organic material, causing a difference in the osmotic potential of the root system and the soil while attenuating the water loss and increases plant resistance to stomatal closure (Lacerda et al., 2003; Silva et al., 2011).

Similar results were obtained by Silva et al. (2013) when there was an increase in saline levels of irrigation water, damaging, thus, the stomatal conductance in string bean plants fertilized with bovine organic fertilizer. The same was attested by Sousa et al. (2016b), when studying the maize culture, in which saline stress inhibited stomatal conductance in the presence and absence of organic fertilizer.

Figure 7 shows that there was a significant reduction in transpiration, with an increase in the concentration of salts in irrigation water. However, this was mitigated by the presence of bovine organic fertilizer (4.65\%). According to Taiz et al. (2017), this is due to reduced leaf growth, a plant defense mechanism under salt stress conditions, in which also reduces perspiration and prevents water loss. Larcher (2006) adds that reducing the amount of transpired water can contribute to the reduction of the absorption and loading of $\mathrm{Na}^{+}$ and $\mathrm{Cl}^{-}$ions to the interior of the plants.

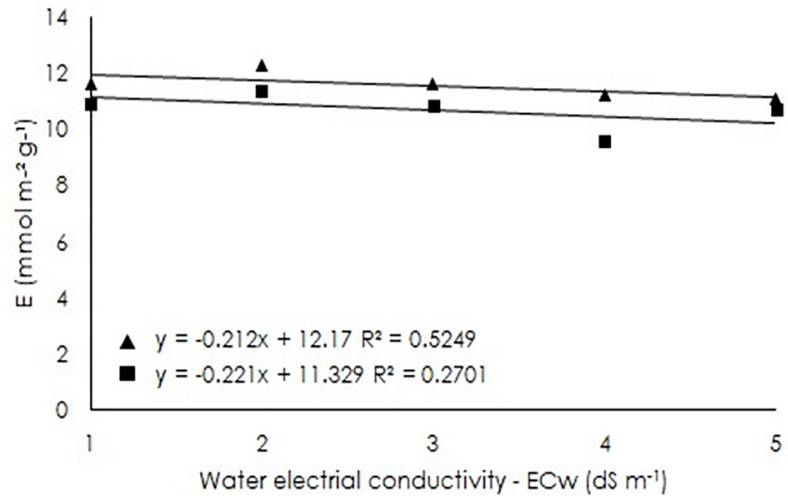

Figure 7. Transpiration values (E) in okra plants irrigated with with different levels of salinity in irrigation in soil with (A) and without (घ) bovine organic fertilizer.

Gomes et al. (2015) when evaluating the sunflower culture found that the irrigation water affected in a linear way the values of transpiration of the plants, being less affected in the presence of the bovine organic fertilizer. Similar results were obtained by Sousa et al. (2014a), working under greenhouse conditions with cowpea. The same was observed by Sousa et al. (2018), when studying the effect of irrigation with saline water in the soybean culture in soil with bovine organic fertilizer. 


\section{Conclusions}

Saline stress affects the initial growth and accumulation of biomass in okra plants.

The organic fertilizer was more efficient in initial growth and biomass in okra plants than in the control treatment.

The increase in the saline concentration of the irrigation water reduced the gas exchange (photosynthesis, stomatal conductance and transpiration) in okra plants, however, in smaller proportions in the soil with the bovine organic fertilizer.

\section{References}

Alencar, T.L., Chaves, A.F., Santos, C.L.A., Assis Júnior, R.N., Mota, J.C.A. 2015. Atributos físicos de um Cambissolo cultivado e tratado com biofertilizante na Chapada do Apodi, Ceará. Revista Brasileira de Ciência do Solo 39: 737-749.

Andrade, J.R., Maia Júnior., S.O., Barbosa, J.W.S., Alencar, A.E.V., Jovino, R.S., Nascimento, R. 2019. Chlorophyll fluorescence as a tool to select salinity-tolerant cowpea genotypes. Comunicata Scientiae 10: 319-324.

Aydin, A., Kant, C., Turan, M. 2012. Humic acid application alleviate salinity stress of bean (Phaseolus vulgaris L.) plants decreasing membrane leakage. African Journal of Agricultural Research 7: 1073-1086.

Balmori, D.M., Spaccini, R., Aguiar, N.O.A., Novotny, E.H., Olivares, F.L., Canellas, L.P. 2014. Molecular Characteristics of Humic Acids Isolated from Vermicomposts and Their Relationship to Bioactivity. Journal Agricultural Food Chemistry 62: 11412-11419.

Caron, V., Pereira, J., Camargo, P. 2015. Condicionadores do solo: ácidos húmicos e fúlvicos. ESALQ, Piracicaba, Brazil. $46 \mathrm{p}$.

Cavalcante, L.F., Vieira, M.D.S., Santos, A.F.D., Oliveira, W.M.D., Nascimento, J.A. M.D. 2010. Água salina e esterco bovino líquido na formação de mudas de goiabeira cultivar Paluma. Revista Brasileira de Fruticultura 32: 251 261.

Coelho, D.S., Simões, W.L., Mendes, A.M.S. Dantas, B.F., Rodrigue, S.J.A.S., Souza, M.A. 2014. Germinação e crescimento inicial de variedades de sorgo forrageiro submetidas ao estresse salino. Revista Brasileira de Engenharia Agrícola e Ambiental 18: 25-30.

Dhiman, S., Dubey, Y.P. 2017. Effect of Biofertilizers and Inorganic Fertilizers on Yield Attributes, Yield and Quality of Triticum aestivum and Zea mays in an Acid Alfisol. International Journal of Current Microbiology and Applied Sciences 6: 2594-2603.

Filgueira, F.A.R. 2012. Novo Manual de Olericultura: Agrotecnologia moderna na produção e comercialização de hortaliças. Editora UFV, Viçosa, Brazil. $421 \mathrm{p}$.
Freire, M.B.G.S., Pessoa, L.G.M., Gheyi, H.R. 2016. Métodos de análises químicas para solos afetados por sais. In: Gheyi, H.R., Dias, N.S., Lacerda, C.F., Gomes Filho, E. Manejo da salinidade na agricultura: Estudos básicos e aplicados. Instituto Nacional de Ciência e Tecnologia em Salinidade, Fortaleza, Brazil. p. 123-148.

García, A.C., García-Mina, J.M., Tavares, O.C.H., Santos, L.A., Berbara, R.L.L. 2018. Substâncias húmicas e seus efeitos sobre a nutrição de plantas. In: Fernandes, M.S., Souza, S.R., Santos, L.A. Nutrição mineral de plantas. SBCS, Viçosa, Brazil. p. 227-277.

Gomes, K.R., Sousa, G.G., Lima, F.A., Viana, T.V.A., Azevedo, B.M., Silva, G.L. 2015. Irrigação com água salina na cultura do girassol (Helianthus annuus L.) em solo com biofertilizante bovino. Irriga 20: 680-693.

Guedes Filho, D.H., Santos, J.B., Gheyi, H.R., Cavalcante, L.F., Santos Junior, J.A. 2015. Componentes de produção e rendimento do girassol sob irrigação com águas salinas e adubação nitrogenada. Irriga 20: 514-527.

Guimarães, I.P., Oliveira, F.N., Vieira, F.E., Torres, S.B. 2013. Efeito da salinidade da água de irrigação na emergência e crescimento inicial de plântulas de mulungu. Revista Brasileira de Ciências Agrárias 8: 137-142.

IBGE. Sistema IBGE de recuperação automática - SIDRA. $2017 . \quad$ https://sidra.ibge.gov.br/ tabela/6619\#resultado<Access in 11 Oct. 2018>

Lacerda, C.F., Cambraia, J., Cano, M.A.O., Ruiz, H.A., Prisco, J.T. 2003. Solute accumulation and distribution during shoot and leaf development in two sorghum genotypes under salt stress. Environmental and Experimental Botany 49: 107-120.

Larcher, W. 2006. Ecofisiologia vegetal. Editora Rima Artes e Textos, São Carlos, Brazil. 550 p.

Lima, L.A., Oliveira, F.D.A., Alves, R.C., Linhares, P.S.F., Medeiros, A.M.A., Bezerra, F.M.S. 2015. Tolerância da berinjela à salinidade da água de irrigação. Revista Agro@mbiente On-line 9: 27-34.

Lúcio, W.S., Lacerda, C.F., Mendes Filho, P.F., Hernandez, F.F.F., Neves, A.L.R., Gomes Filho, E. 2013. Crescimento e respostas fisiológicas do meloeiro inoculado com fungos micorrízicos arbusculares sob estresse salino. Semina. Ciências Agrárias 34: 1587-1602.

Malavolta, E., Vitti, G.C., Oliveira, S.A. 1997. Avaliação do estado nutricional das plantas: princípios e aplicações. POTAFOS, Piracicaba, Brazil. 201 p.

Medeiros, R.F., Cavalcante, L.F., Mesquita, F.O., Rodrigues, R.M., Sousa, G.G., Diniz, A.A. 2011. Crescimento inicial do tomateiro-cereja sob irrigação com águas salinas em solo com biofertilizantes bovino. Revista Brasileira de Engenharia Agrícola e Ambiental 15: 505-51 1.

Mota, W.F., Finger, F.L., Silva, D.J.H., Corrêa, P.C., Firme, L.P., Ribeiro, R.A. 2008. Composição mineral de frutos de quatro cultivares de quiabeiro. Ciência e Agrotecnologia 32: $762-767$. 
Nascimento, P.S., Paz, V.P.S., Fraga Júnior, L.S., Costa, I.P. 2017. Crescimento vegetativo do quiabeiro em função da salinidade da água de irrigação e da adubação nitrogenada. Colloquium Agrariae 13: 10-15.

Oliveira, F.A., Pinto, K.S.O., Bezerra, F.M.S., Lima, L.A., Cavancante, A.L.G., Oliveira, M.K.T. \& Medeiros, J.F. 2014 Tolerância do maxixeiro, cultivado em vasos, à salinidade da água de irrigação. Revista Ceres 61: 147-154.

Oliveira, W.J., Souza, E.R., Cunha, J.C., Silva, Ê.F.F., Veloso, V.L. 2017. Leaf gas exchange in cowpea and $\mathrm{CO}_{2}$ effluxin soil irrigated with saline water. Revista Brasileira de Engenharia Agrícola e Ambiental 21: 32-37.

Puértolas, J., Larsen, E.K., Davies, W.J., Dodd, I.C. 2017. Applying 'drought' to potted plants by maintaining suboptimal soil moisture improves plant water relations. Journal of Experimental Botany 68: 2413-2424.

Reges, K.S.L., Viana, T.V.A., Sousa, G.G., Santos, F.S.S., Lacerda, C.F., Azevedo, B.M. 2017. Estresse salino em plantas de pimentão em sistema semi-hidropônico sob fertilização orgânica e mineral. Revista Brasileira de Agricultura Irrigada 11: 1813-1824.

Rhoades, J.D., Kandiah, A., Mashali, A.M. 2000. Uso de águas salinas para produção agrícola. UFPB, Campina Grande, Brazil. 117 p.

Santos, H.G., Jacomine, P.K.T., Anjos, L.H.C., Oliveira, V.A., Lumbreras, J.F., Coelho, M.R., Almeida, J.A., Cunha, T.J.F., Oliveira, J.B. 2018. Sistema Brasileiro de Classificação de Solos. Editora Embrapa, Brasília, Brazil. 590 p.

Shahid, M.A., Pervez, M.A., BalaL, R.M., Ahmad, R., Ayyub, C.M., Abbas, T., Akhtar, N. 2011 . Salt stress effects on some morphological and physiological characteristics of okra (Abelmoschus esculentus L.). Soil \& Environment 30: 66-73.

Silva, F.L.B., Lacerda, C.F., Neves, A.L.R., Sousa, G.G., Sousa, C.H.C., Ferreira, F.J. 2013. Irrigação com águas salinas e uso de biofertilizante bovino nas trocas gasosas e produtividade de feijão-de-corda. Irriga 18: 304-317.

Silva, F.L.B., Lacerda, C.F., Sousa, G.G., Neves, A.L., Silva, G.L., Sousa, C.H. 2011. Interação entre salinidade e biofertilizante bovino na cultura do feijão-de-corda. Revista Brasileira de Engenharia Agrícola e Ambiental 15: 383-390.

Sousa, G.G., Viana, T.V.A., Lacerda, C.F., Azevedo, B.M., Silva, G.L., Costa, F.R.B. 2014a. Estresse salino em plantas de feijão-caupi em solo com fertilizantes orgânicos. Revista Agro@mbiente 8: 359-367.

Sousa, G.G., Fiusa, J.N., Leite, K.N., Soares, S.C., Silva, G.L. 2017. Água salina e biofertilizante de esterco bovino na cultura do gergelim. Revista Agropecuária Técnica 38: 116-125.

Sousa, G.G., Lima, F.A., Gomes, K.R., Viana, T.V.D.A., Costa, F.R.B., Azevedo, B.M., Martins, L.F. 2014b. Irrigação com água salina na cultura do amendoim em solo com biofertilizante bovino. Nativa 2: 89-94.

Sousa, G.G., Marinho, A.B., Albuquerque, A.H.P, Viana,
T.V.A., Azevedo, B. M. 2012b. Crescimento inicial do milho sob diferentes concentrações de biofertilizante bovino irrigado com águas salinas. Revista Ciência Agronômica 43: 237-245.

Sousa, G.G., Rodrigues, V.S., Soares, S.C., Damasceno, Í.N., Fiusa, J.N., Saraiva, S.E.L. 2018. Irrigation with saline water in soybean (Glycine max (L.) Merr.) in a soil with bovine biofertilizer. Revista Brasileira de Engenharia Agrícola e Ambiental 22: 604-609.

Sousa, G.G., Rodrigues, V.S., Viana, T.V.A., Silva, G.L., Rebouças Neto, M.O., Azevedo, B.M. 2016a. Irrigação com água salobra na cultura do rabanete em solo com fertilizantes orgânicos. Revista Brasileira de Agricultura Irrigada 10: 1065-1074.

Sousa, G.G., Viana, T.V.A., Silva, G.L., Dias, C.N., Azevedo, B.M. 2016 b. Interação entre salinidade e biofertilizante de caranguejo na cultura do milho. Magistra 28: 44-53.

Sousa, G.G., Santos, E.M., Viana, T.V.A., Oliveira, C.M.B., Alvino, F.C.G., Azevedo, B.M. 2013a. Fertirrigação com biofertilizante bovino na cultura do feijoeiro. Revista Agropecuária Cientifica no Semiárido 9: 76-82.

Taiz, L., Zeiger, E. Moller, I.M. Murphy, A. 2017. Fisiologia vegetal. Editora Artmed, Porto Alegre, Brazil. 858 p.

Véras, M.L.M., Melo Filho, J.S., Araújo, D.L., Alves, L.S., Irineu, T.H.S., Andrade, R. 2015. Salinidade da água e biofertilizante bovino na formação de mudas de mamoeiro (Carica papaya L.). Agropecuária Técnica 36: 212-221.

Conflict of Interest Statement: The authors declare that the research was conducted in the absence of any commercial or financial relationships that could be construed as a potential conflict of interest.

All the contents of this journal, except where otherwise noted, is licensed under a Creative Commons Attribution License attribuition-type BY. 